\title{
Perbandingan Tatalaksana Konstipasi Kronis antara Disimpaksi per Oral dengan per Rektal di Instalasi Kesehatan Anak RS DR Sardjito Yogyakarta
}

\author{
Wahyu Damayanti, Pradini, Zamrina, M. Juffrie \\ Bagian Ilmu Kesehatan Anak Fakultas Kedokteran Universitas Gadjah Mada - RS DR Sardjito, Yogyakarta
}

\begin{abstract}
Latar belakang. Konstipasi adalah kelainan yang sering terjadi dan menimbulkan masalah yang serius pada bayi dan anak. Penyebab konstipasi dapat dibagi menjadi penyebab non organik/fungsional dan penyebab organik. Tatalaksana anak dengan konstipasi fungsional meliputi beberapa langkah, 1) edukasi, 2) pengeluaran feses/disimpaksi, 3) fase pemeliharaan. Pada disimpaksi dan fase pemeliharaan diperlukan laksansia secara oral ataupun rektal.

Tujuan. Membandingkan disimpaksi oral (Laktulose) dengan per rektal (phosphate enema) pada anak dengan konstipasi kronis, kedua obat ini dari golongan yang sama yaitu laksansia osmotik

Metode. Merupakan penelitian uji klinis acak terkendali. Sampel penelitian adalah anak konstipasi fungsional yang berobat jalan dan dirawat di Instalasi Kesehatan Anak RS Dr. Sardjito Yogyakarta dan memenuhi kriteria inklusi dan kriteria eksklusi, usia antara $\geq 6$ bulan - 14 tahun akan dilakukan uji disimpaksi per oral atau per rektal. Hasil. Angka kesembuhan pada kelompok terapi per oral lebih sedikit dibanding per rektal $(=0,636$, IK 95\% 0, 336-1,205), $\mathrm{p}=0$, 162. Efek samping yang timbul yaitu kembung ( $R R=0,857$, IK 95\% 0,633-1,160), $\mathrm{p}=0,285$, nyeri perut $(\mathrm{RR}=0,583$, IK 95\% 0,141-2,410), $\mathrm{p}=0,312$, diare $(\mathrm{R} R=0,952$, IK 95\% 0,611-1,484), $\mathrm{p}=0$,832. Penerimaan terhadap obat yang diberikan pada anak $(\mathrm{R}=1,000$, IK 95\% 0,699-1,448), $\mathrm{p}=1,000$, pada orang tua $(R R=1,1670$, IK 95\% 0,862-1,579), $p=0,317$. Perubahan gejala konstipasi setelah intervensi obat, yaitu retensi ( $R R=1,40$, IK 95\% 0,112-17,543), $p=0,802$, soiling ( $R R=1,40$, IK 95\% 0,875-2,237), $\mathrm{p}=0,171$, konsistensi feses ( $R R=1,20$, IK 95\% 0,839 -1,716), p=0,071.

Kesimpulan. Tidak terdapat perbedaan efektifitas pada kedua kelompok, hanya dalam lama terapi lebih cepat pada laksansia per rektal dibandingkan per oral. Tidak terdapat perbedaan yang bermakna pada kedua kelompok dalam mengurangi retensi, nyeri saat defekasi dan konsistensi feses. Tidak ditemukan efek samping yang bermakna pada pemakaian laksansia per oral ini. Laksansia per oral lebih mudah diberikan dibanding laksansia per rektal walau hasil tidak berbeda bermakna. Sari Pediatri 2012;14(4):224-9.
\end{abstract}

Kata kunci: konstipasi fungsional, disimpaksi, lama terapi

\footnotetext{
Alamat korespondensi:

Dr. Wahyu Damayanti, Sp.A. Bagian Ilmu Kesehatan Anak FK Universitas Gadjah Mada - RS DR Sardjito. Jl. Kesehatan No. 1, Yogyakarta. Telp. (0274) 587333, (0274) 561616. E-mail:adit_ardian@yahoo.com
}

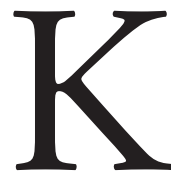

onstipasi adalah kelainan yang sering terjadi pada bayi dan anak. Sampai saat ini belum terdapat penelitian yang mengamati dan menghitung berapa angka kejadian 
konstipasi di Indonesia. Di Amerika angka kejadian konstipasi berkisar antara 2\%-15\%, sedangkan di Eropa bervariasi antara 3\%-20\%. Di Amerika, hampir sekitar $3 \%$ dari anak yang datang ke klinik dokter anak adalah karena konstipasi, dan lebih dari 25\% dirujuk ke ahli gastroenterologi anak. Walaupun demikian penyebab konstipasi terbanyak pada anak karena gangguan fungsional. Hanya sebagian kecil konstipasi pada anak disebabkan oleh gangguan organik atau anatomi. ${ }^{2}$

Tata laksana anak dengan konstipasi fungsional meliputi beberapa langkah, 1) edukasi, 2) disimpaksi, dan 3) pemeliharaan. Terapi tersebut meliputi pemberian diet tinggi serat, modifikasi behavioral atau sikap yang benar terhadap perasaan untuk buang air besar, dan penggunaan laksansia rutin sampai tercapai pola buang air besar yang normal. ${ }^{1}$ Pembersihan skibala dapat menggunakan obat per oral atau per rektal, walaupun belum ada penelitian randomisasi yang membandingkan efektifitas dari obat per oral dengan per rektal pada pengeluaran skibala, dari penelitian klinik tanpa kontrol menunjukkan kedua obat tersebut memberikan hasil yang sama efektif. ${ }^{3}$ Kelebihan obat oral adalah tidak invasif namun menyebabkan ketergantungan, sedangkan obat per rektal lebih cepat berhasil namun bersifat invasif. Beberapa obat laksansia per rektal seperti sorbitol, senna, bisacodyl, glicerin telah sering digunakan dengan hasil yang baik, namun belum ada penelitian klinik dengan kontrol yang memperlihatkan efektifitas maupun efikasi dari obat-obat tersebut. Rajindrajith ${ }^{4}$ menyebutkan hanya sedikit penelitian acak terkendali yang membahas tentang pilihan terapi konstipasi yang dapat digunakan. Masih sedikit yang diketahui tentang dosis terapi optimum dan efek samping jangka panjang obat konstipasi, sehingga manajemen konstipasi pada anak terutama berdasarkan pada pengalaman individu.

Dari latar belakang tersebut di atas timbul masalah yang dapat dirumuskan sebagai berikut, Apakah disimpaksi per oral dapat memberikan efek laksatif lebih baik pada anak dengan konstipasi dibandingkan dengan anak yang mendapat disimpaksi per rektal? Penelitian kami bertujuan untuk mempelajari efek laksatif obat per oral pada anak dengan konstipasi dibandingkan dengan efek laksatif obat per rektal.

\section{Metode}

Penelitian uji klinis acak terkontrol untuk membandingkan efek laksansia per oral dengan per rektal pada anak dengan konstipasi. Subyek penelitian adalah anak dengan konstipasi kronis dengan penyebab gangguan fungsional yang berobat jalan dan dirawat di Instalasi Kesehatan Anak RS DR Sardjito selama bulan Mei - November 2009 dan memenuhi kriteria inklusi dan ekslusi. Kriteria inklusi meliputi, 1) terdiagnosis konstipasi fungsional, yang berobat jalan atau rawat inap pada bulan Mei 2009 - November 2009, 2) usia $\geq 6$ bulan- 14 tahun. Kriteria eksklusi meliputi, 1) mendapat laksansia lain, 2) terdapat kontraindikasi untuk asupan per oral.

\section{Bahan dan cara penelitian}

Subyek yang terpilih dilakukan randomisasi alokasi dengan menggunakan komputer, untuk mendapatkan nasehat dan laksansia per oral atau per rektal. Subyek akan mengikuti penelitian selama satu minggu. Subyek penelitian akan menjalani pemeriksaan awal dan akhir penelitian yang terdiri dari anamnesis dan pemeriksaan fisik, pemeriksaan colok dubur, dan nasehat. Anamnesis terdiri dari identitas, riwayat penyakit, faktor risiko, penyakit lain yang sedang diderita, jenis, dan obat yang diminum selain perlakuan yang diberikan. Orang tua juga diberi penjelasan tentang jalannya penelitian dan kuesioner yang harus diisi setiap hari oleh orang tua. Kuesioner berisi data tentang jenis obat yang diberikan, dosis obat, efek terapi (onset dan frekuensi defekasi, konsistensi feses) dan efek samping yang timbul (kembung, nyeri perut, diare). Selama penelitian, subyek penelitian diminta segera kembali ke rumah sakit bila terdapat efek samping yang sangat mengganggu. Data dianalis uji statistik chi square untuk data nominal, dengan tingkat kemaknaan $\mathrm{p}<0,05$. Student $t$-test digunakan untuk data berkelanjutan.

\section{Hasil}

Duapuluh anak yang sesuai dengan kriteria inklusi dan eksklusi diikutsertakan dalam penelitian. Subyek penelitian dibagi dalam dua kelompok yaitu 10 anak pada terapi per oral dan 10 anak pada terapi per rektal. Pada kelompok terapi per oral terdapat drop-out 1 orang, sehingga 9 dianalisis pada kelompok per oral dan 10 pada kelompok per rektal. Tabel 2 tertera karakteristik gejala-gejala konstipasi pada kedua kelompok umur, juga tertera bahwa soiling dan enkopresis lebih banyak 
ditemukan pada anak usia kurang dari 4 tahun, sedangkan nyeri saat defekasi, terbanyak dalam 7-30 hari, konsistensi keras terbanyak ditemukan pada anak usia lebih dari 4 tahun, untuk gejala lain hampir sama antara kedua kelompok usia.

Kelompok terapi per oral memiliki angka kesembuhan lebih sedikit dari kelompok terapi per rektal dengan RR 0,635 (95\% IK:0,335-1,205) namun perbedaan tidak bermakna $(\mathrm{p}=0,162)$ (Tabel 3). Efek samping yang timbul selama penelitian adalah kembung, nyeri perut, diare, dan ketiganya berbeda tidak bermakna antara kelompok terapi per oral dan kelompok terapi per rektal.

Pada Tabel 4 tertera bahwa tidak ada perbedaan yang bermakna dalam hal penerimaan anak dan orangtua terhadap kedua macam obat yang diberikan
Tabel 5 menunjukkan perubahan masing-masing gejala konstipasi berdasarkan kriteria Roma. Setelah pemberian intervensi, terlihat bahwa terapi oral lebih sedikit menyebabkan perubahan pada kejadian retensi (RR 1,40; 95\% IK 0,112-17,543), soiling (RR 1,40; 95\% IK 0,876-2,237), dan enkopresis (RR 1,20; 95\% IK 0,839-1,716) namun perbedaan tidak bermakna.

Lama terapi pada kelompok terapi oral baik pada hari pertama (Gambar 1), kedua (Gambar 2), dan ketiga (Gambar 3) tampak lebih lama dibandingkan dengan kelompok terapi per rektal. Pada hari pertama lebih kurang tinggal $50 \%$ anak yang sudah $\mathrm{BAB}$ pada menit-menit awal setelah pemberian terapi per rektal, sedangkan pada kelompok terapi oral $50 \%$ baru $\mathrm{BAB}$ setelah menit ke $120(\mathrm{p}=0,0090)$. Pada hari kedua 50\% anak pada kelompok terapi per rektal BAB pada menit-

Tabel 1. Karakteristik dasar subyek penelitian

\begin{tabular}{|c|c|c|c|c|}
\hline & $\begin{array}{l}\text { Terapi per oral } \\
n=9\end{array}$ & $\begin{array}{l}\text { Terapi per rektal } \\
n=10\end{array}$ & $\begin{array}{l}\text { Uji } \\
\mathrm{x} 2 / \mathrm{t}\end{array}$ & $\mathrm{p}$ \\
\hline Umur, bulan (rerata, SB) & $39,20 \pm 42,48$ & $36,89 \pm 51,38$ & 0,040 & 0,843 \\
\hline Durasi konstipasi terakhir, hari (rerata, SB) & $2,88 \pm 1,96$ & $4,56 \pm 2,19$ & 0,186 & 0,672 \\
\hline \multicolumn{5}{|l|}{ Jenis kelamin } \\
\hline Laki-laki & 4 & 2 & & \\
\hline Perempuan & 6 & 7 & 0,656 & 0,418 \\
\hline \multicolumn{5}{|l|}{ Pendidikan ayah } \\
\hline$<$ SLTA & 4 & 4 & & \\
\hline$\geq$ SLTA & 4 & 4 & 0,000 & 1,000 \\
\hline \multicolumn{5}{|l|}{ Pendidikan ibu } \\
\hline$<$ SLTA & 5 & 4 & & \\
\hline$\geq$ SLTA & 4 & 4 & 0,049 & 0,824 \\
\hline \multicolumn{5}{|l|}{ Lama konstipasi } \\
\hline$<3$ bulan & 3 & 3 & & \\
\hline$\geq 3$ bulan & 7 & 6 & 0,024 & 0,876 \\
\hline \multicolumn{5}{|l|}{ Diet serat } \\
\hline Kurang serat & 3 & 2 & & \\
\hline Cukup serat & 7 & 6 & 0,052 & 0,819 \\
\hline
\end{tabular}

Tabel 2. Karakteristik gejala konstipasi subyek penelitian berdasarkan kriteria Roma

\begin{tabular}{lcc} 
& $\begin{array}{c}\text { Usia } \leq 4 \text { tahun } \\
\mathrm{n}=15\end{array}$ & $\begin{array}{c}\text { Usia }>4 \text { tahun } \\
\mathrm{n}=4\end{array}$ \\
\hline Frekuensi defekasi/minggu, (mean, SD) & $2,80 \pm 2,51$ & $2,00 \pm 0,82$ \\
Retensi & 11 & 3 \\
Soiling & 7 & 1 \\
Enkopresis & 4 & 0 \\
Nyeri saat defekasi & 10 & 4 \\
Defekasi banyak dalam $7-30$ hari & 7 & 4 \\
Konsistensi keras & 8 & 3 \\
\hline
\end{tabular}


Tabel 3. Efek terapi dan efek samping yang muncul

\begin{tabular}{lccccc}
\hline & $\begin{array}{c}\text { Terapi per } \\
\text { oral }\end{array}$ & $\begin{array}{c}\text { Terapi per } \\
\text { rektal }\end{array}$ & Uji F & p & $\begin{array}{c}\text { RR } \\
(95 \% \text { IK })\end{array}$ \\
\hline $\begin{array}{l}\text { Kesembuhan } \\
\quad \text { Ya }\end{array}$ & 5 & 7 & 1,959 & 0,162 & 0,635 \\
$\quad$ Tidak & 4 & 1 & & & $(0,335-1,205)$ \\
$\begin{array}{l}\text { Efek samping obat } \\
\quad \text { Kembung }\end{array}$ & 1 & 0 & 1,143 & 0,285 & $0,857(0,633-1,160)$ \\
$\quad$ Nyeri perut & 1 & 2 & 1,020 & 0,312 & $0,583(0,141-2,410)$ \\
$\quad$ Diare & 1 & 1 & 0,045 & 0,832 & $0,952(0,611-1,484)$ \\
\hline
\end{tabular}

Tabel 4. Penerimaan anak dan orangtua terhadap obat yang diberikan

\begin{tabular}{lccccc}
\hline & $\begin{array}{c}\text { Terapi per } \\
\text { oral }\end{array}$ & $\begin{array}{c}\text { Terapi per } \\
\text { rektal }\end{array}$ & $\begin{array}{c}\text { Uji } \\
\mathrm{x} 2 / \mathrm{t}\end{array}$ & $\mathrm{p}$ & $\begin{array}{c}\mathrm{RR} \\
(95 \% \mathrm{IK})\end{array}$ \\
\hline $\begin{array}{l}\text { Anak mudah konsumsi obat } \\
\quad \text { Ya }\end{array}$ & 7 & 7 & 0,000 & 1,000 & $1,000(0,699-1,448$ \\
$\quad$ Tidak & 1 & 1 & & & \\
$\begin{array}{l}\text { Orangtua mudah memberi obat } \\
\quad \text { Ya }\end{array}$ & 7 & 6 & 1,000 & 0,317 & $1,167(0,862-1,579)$ \\
$\quad$ Tidak & 0 & 1 & & & \\
$\begin{array}{l}\text { Aktivitas sehari-hari } \\
\quad \text { Normal } \\
\quad \text { Berkurang }\end{array}$ & 7 & 6 & 1,000 & 0,317 & $1,167(0,862-1,579)$ \\
$\begin{array}{l}\text { Anak merasa puas setelah BAB } \\
\quad \text { Ya }\end{array}$ & 0 & 1 & & & \\
$\quad$ Tidak & 4 & 6 & 0,063 & 0,802 & $0,933(0,548-1,590)$ \\
\hline
\end{tabular}

Tabel 5. Jumlah pasien yang mengalami perubahan gejala konstipasi

\begin{tabular}{|c|c|c|c|c|c|}
\hline & $\begin{array}{l}\text { Terapi per } \\
\text { oral }\end{array}$ & $\begin{array}{l}\text { Terapi per } \\
\text { rektal }\end{array}$ & $\begin{array}{c}\mathrm{Uji} \\
\mathrm{X} 2 / \mathrm{t}\end{array}$ & $\mathrm{p}$ & $\begin{array}{c}\text { RR } \\
(95 \% \mathrm{IK})\end{array}$ \\
\hline \multicolumn{6}{|c|}{ Frekuensi defekasi/hari (mean, SD) } \\
\hline Hari 1 & $2 \pm 1,22$ & $2,57 \pm 2,57$ & 1,451 & 0,256 & - \\
\hline Hari 2 & $1,75 \pm 1,50$ & $1,86 \pm 1,21$ & 0,127 & 0,730 & \\
\hline Hari 3 & $1,60 \pm 1,34$ & $1,20 \pm 0,45$ & 2,844 & 0,130 & \\
\hline Retensi & 1 & 1 & 0,063 & 0,802 & $\begin{array}{c}1,40 \\
(0,112-17,543)\end{array}$ \\
\hline Soiling & 0 & 2 & 1,870 & 0,171 & $\begin{array}{c}1,40 \\
(0,876-2,237)\end{array}$ \\
\hline Enkopresis & 0 & 1 & 0,067 & 0,414 & $\begin{array}{c}1,20 \\
(0,839-1,716)\end{array}$ \\
\hline Konsistensi & 1 & 4 & 3,252 & 0,071 & - \\
\hline
\end{tabular}

menit awal, sedangkan pada kelompok terapi oral 50\% pada menit ke-300 ( $\mathrm{p}=0,0184)$. Demikian pula pada hari ketiga, $50 \%$ anak pada kelompok terapi per rektal BAB pada menit-menit awal setelah pemberian terapi, sedangkan $50 \%$ anak pada kelompok terapi oral baru berak pada menit ke $350(\mathrm{p}=0,3715)$.

\section{Pembahasan}

Manfaat penelitian kami untuk mengetahui efektivitas laksansia per oral sebagai laksansia pada anak dengan konstipasi fungsional. Laksansia per oral dapat berperan sama baiknya dengan per rektal dengan 


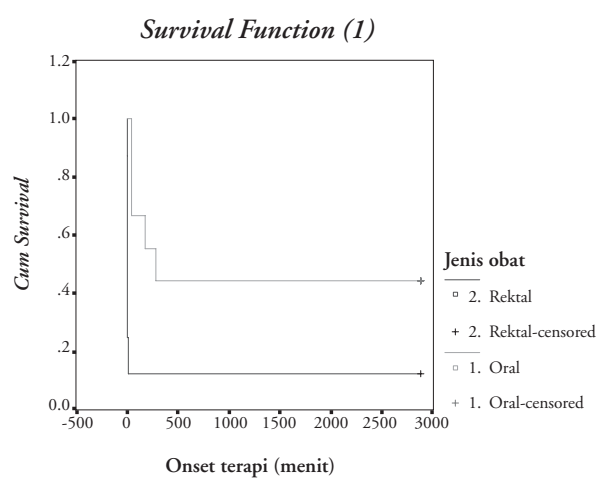

Gambar 1
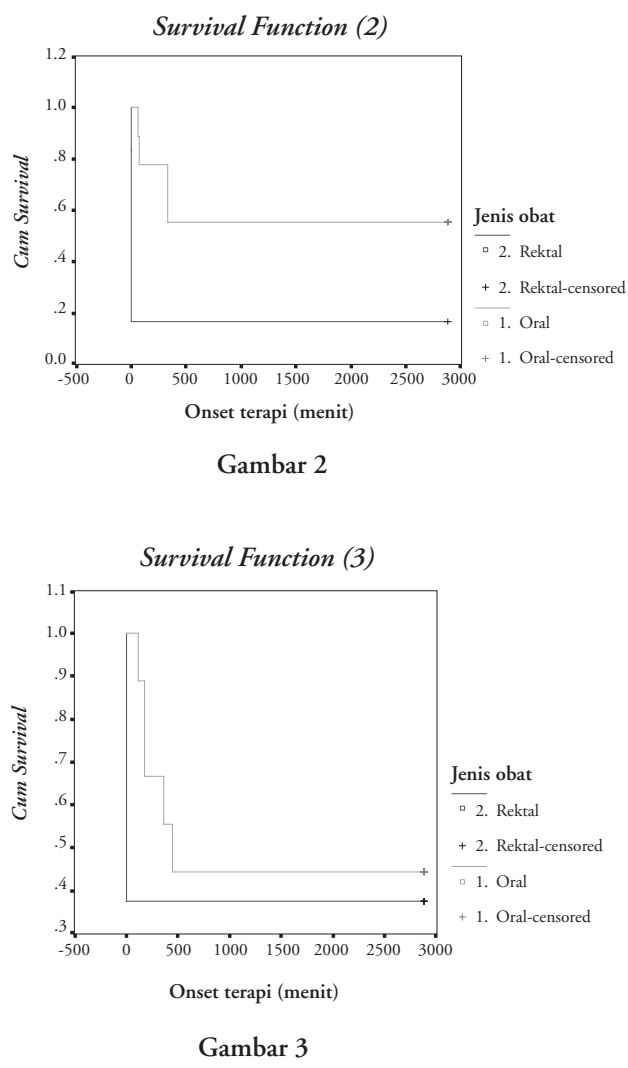

bukti tidak terdapat perbedaan bermakna pada kesembuhan di antara kedua macam obat tersebut Kesembuhan konstipasi fungsional pada anak umum terjadi dalam waktu relatif lama yaitu sekitar 6 bulan. Kami menggunakan evaluasi pada hari ke-1, 2, dan 3 dimaksudkan untuk mengetahui kecepatan efek laksansia untuk disimpaksi feses. Evaluasi dalam 3 hari tersebut berdasarkan hasil penelitian oleh Benninga $\mathrm{dkk}^{5}$ yang menyebutkan perlu dilakukan disimpaksi feses dalam 3-7 hari berturut-turut dalam tatalaksana konstipasi fungsional.
Dalam hal kecepatan efek laksansia memang terlihat bahwa kelompok terapi per rektal lebih cepat dibanding kelompok terapi oral dengan melihat tabel survival function, hasil tersebut sesuai dengan penelitian terdahulu yang menyebutkan bahwa kecepatan efek laksansia per rektal lebih cepat dibandingkan dengan per oral. ${ }^{6}$

Kesembuhan pada konstipasi fungsional dipengaruhi oleh beberapa faktor yaitu asupan serat makanan, jumlah cairan setiap hari, lama konstipasi, dan jenis perawatan. Jumlah serat makanan dan cairan yang kurang, konstipasi yang sudah berlangsung lama atau anak yang memiliki aktivitas kurang karena perawatan tirah baring yang lama akan mempersulit proses penyembuhan. Pada penelitian kami sebagian besar anak pada kedua kelompok perlakuan memiliki asupan serat dan cairan yang cukup dan konstipasi yang terjadi sudah berlangsung lama (lebih dari tiga bulan). Maka efek kesembuhan yang didapat pada penelitian kami adalah efek dari intervensi laksansia.

Kami menemukan bahwa pemberian laksansia per oral lebih mudah diterima oleh anak dan juga orangtua walaupun tidak terdapat perbedaan yang bermakna. Demikian pula dalam hal aktivitas anak tidak terdapat perbedaan yang bermakna pada kedua kelompok terapi. Pada penelitian Farahmand $\mathrm{dkk}^{7}$ efek samping pada pemakaian laksansia adalah peningkatan kadar hidrogen pernafasan, nyeri perut, kembung, flatulen, dan diare. Pada penelitian kami efek samping yang dinilai adalah kembung, nyeri perut, dan diare karena keterbatasan dalam mengevaluasi peningkatan kadar hidrogen pernafasan dan flatulen. Kami mendapatkan gejala kembung, nyeri perut, diare yang kejadiannya sama pada kedua kelompok terapi.

Setelah pemberian intervensi, terlihat bahwa terapi oral lebih sedikit menyebabkan perubahan pada kejadian retensi, soiling, dan enkopresis namun perbedaannya tidak bermakna, demikian pula dalam hal frekuensi dan konsistensi feses tidak terdapat perbedaan yang bermakna, hal tersebut mungkin disebabkan efek terhadap retensi, soiling, dan enkopresis belum terlihat karena memerlukan waktu terapi yang lebih panjang.

Kelemahan penelitian kami terletak pada kriteria inklusi dan kekuatan penelitian. Pada penelitian kami kriteria untuk menyingkirkan penyebab konstipasi organik hanya berdasarkan klinis, yaitu dari anamnesis dan pemeriksaan fisik. Hal tersebut disebabkan keterbatasan peneliti dalam menyingkirkan penyebab 
konstipasi organik menurut uji diagnostik yang seharusnya. Jumlah sampel yang terkumpul tidak mencukupi perhitungan sampel awal karena waktu penelitian yang kurang. Pada perhitungan sampel menggunakan referensi angka kesembuhan konstipasi bukan berdasarkan pemakaian masing-masing laksansia namun berdasarkan angka kesembuhan konstipasi setelah pemakaian serat makanan. Hal tersebut disebabkan karena tidak didapatkan data-data yang sesuai dari penelitian lain (belum terdapat penelitian lain yang memakai preparat yang hampir sama dengan yang digunakan pada penelitian kami).

\section{Kesimpulan}

Laksansia per oral memiliki efektifitas yang tidak berbeda bermakna dengan laksansia per rektal hanya dalam hal lama terapi lebih cepat pada laksansia per rektal dibandingkan per oral. Laksansia per oral dapat mengurangi retensi, nyeri saat defekasi, dan konsistensi feses walau hasil tidak berbeda bermakna. Tidak ditemukan efek samping yang bermakna pada pemakaian laksansia per oral. Laksansia per oral lebih mudah diberikan dibanding laksansia per rektal walau hasil tidak berbeda bermakna.

\section{Daftar pustaka}

1. NASPGHAN. Constipation Guideline Committee.
Clinical practice guideline. Evaluationand and treatment of constipation in infants and children: recommendation of the North American Society for Pediatric Gastroenterology, Hepatology and Nutrition. J Pediatr Gastroenterol Nutr 2006;43:1-13.

2. Jurgens H, Oster C, Fereday J. Management of chronic functional constipation in children: a review of the literatur. Neonatal, Paediatric and Child Health Nursing 2011;14:23-8.

3. Candy David C.A, Edwards D, Geraint M. Treatment of faecal impaction with polyethelene glycol plus electrolytes $(\mathrm{PGE}+\mathrm{E})$ followed by a double-blind comparison of $\mathrm{PEG}+\mathrm{E}$ versus lactulose as maintenance therapy. J Pediatr Gastroenterol and Nutr 2006;43:65-70.

4. Rajindrajith S, Devanarayana N.M. Constipation in children: novel insight into epidemiology, pathophysiology and management. J Neurogastroenterol Motil 2011;17:35-47.

5. Bekkali $N$, van den Berg $M$, Benninga $M$. Rectal faecal impaction treatment in childhood constipation: enemas versus high doses oral PEG. Pediatrics 2009; 124:e1108-15.

6. Richard B, Colletti MD. Evaluation and treatment of constipation in infant and children: Recommendations of the North American Society for Pediatric Gastroenterology, Hepatology and Nutrition. J Pediatri Gastroentral Nutr 2006; 43:e1-e13.

7. Farahmand F, Eftekhari K, Modarresi V. Comparing oral route paraffin oil versus rectal route for disimpaction in children with cchronic constipation; a randomized control trial. Iran J Pediatr 2010;20:291-6. 